\title{
DEVELOPMENT OF LOW W ASTE TECHNOLOGY OF WATER PURIFICATION FROM COPPER IONS
}

\author{
Ganna Trokhymenko1, * , M ykola Gomelya ${ }^{2}$
}

https:

\begin{abstract}
The results of the water stabilization treatment studies to feed the cooling water circulation systems by ion exchange method are reported. The processes of the water softener on strongly and weakly acidic cation resins in the presence of copper ions are studied. The relation of the water purification efficiency from copper and its softening depending on the form of the ion-exchanger and water consumption was determined.
\end{abstract}

Keywords: cation resin, heavy metals, ion exchange, ionexchanger regeneration, water circulating systems.

\section{Introduction}

At Ukrainian power plants water circulation cooling systems are currently used, the charging of which is performed without the preparatory water softening. To ensure the water stability in relation to the deposition of sediments on the heat exchange equipment the acceptable levels of hardness and alkalinity of water are maintained by regulating the discharge of water on systems blowing. Considering that the water hardness in most water supply sources is more than $4 \mathrm{mg}$-equ/ $\mathrm{dm}^{3}$ and carbonate hardness and alkalinity reach $3.9 \mathrm{mg}-\mathrm{eq} / \mathrm{dm}^{3}$ or more, the volume of the discharge of water on systems blowing reaches fairly large quantities. Thus, in the Zaporizhzhya NPP the discharge of water blowing ranges from 10 to $15 \mathrm{~m}^{3} / \mathrm{s} \quad\left(864000-1296000 \mathrm{~m}^{3} /\right.$ day). The problem is complicated by the fact that due to objective reasons water in circulation systems of power plants is contaminated with heavy metal ions and most of all - copper ions. Thus, according to the data $[1,2]$ the content of copper ions in the cooling pond reaches $0.023-0.0374 \mathrm{mg} / \mathrm{dm}^{3}$ at the background concentration of copper ions in the Kakhovka reservoir which is equal to $0.006 \mathrm{mg} / \mathrm{dm}^{3}$. At the current requirements for water quality in the reservoirs for

\footnotetext{
${ }^{1}$ National University of Shipbuilding

9, Stalingrad Heroes Ave., 9; 54025 Mykolaiv, Ukraine;

${ }^{2}$ National Technical University of Ukraine "KPI"

37, Peremogy Ave., build. 4, 03056 Kyiv, Ukraine; m.gomelya@kpi.ua antr@ukr.net

(C) Trokhymenko G., Gomelya M., 2017
}

industrial fishing at the discharge of waters on systems blowing in the control section the copper concentration should not exceed $0.007 \mathrm{mg} / \mathrm{dm}^{3}$, and in the channel in which water is discharged from the cooling pond the copper concentration should not exceed $0.01 \mathrm{mg} / \mathrm{dm}^{3}$. But taking into account the flow of copper with water which flows to charge the cooling systems and copper flow only from the turbine condenser, the concentration of copper in water that is discharged reaches $0.02-0.03 \mathrm{mg} / \mathrm{dm}^{3}$. This is 2-3 times higher than the acceptable level. Therefore, to solve the problem by regulating the discharge of water on systems blowing is impossible. This applies not only to Zaporizhzhya NPP, but also to all power facilities which discharge water into the reservoirs for industrial fishing.

It is difficult to solve the problem of water purification from copper ions at their concentrations of $0.02-0.07 \mathrm{mg} / \mathrm{dm}^{3}$ and the hardness ions concentrations of $40-100 \mathrm{mg} / \mathrm{dm}^{3}$.

The best option is to improve the technology of water treatment by softening the water which is supplied to the systems charging. With a significant decrease of carbonate water hardness in water circulating systems we can significantly reduce the discharge of water on systems blowing, and thus reduce the intake of natural water. Then solving the problem of conditioning of water, that is supplied to charge the cooling systems, is quite reliable, as well as the protection of water reservoirs from copper ions contamination.

The article aim was to determine the effectiveness of copper ions extraction from water in the presence of hardness ions at its softening, the study of regeneration processes of ion-exchange resins, the development of the low waste technology of water purification from copper ions at its softening to reduce the discharge of water on power plants cooling systems blowing and protection of water reservoirs from copper ions contamination.

\section{Experimental}

The weak-acid cation-exchange resin DOWEXMAC- 3 in acid and salt forms and the strong-acid cationexchange resin KY-2-8 in a salt form were used in the 
work. The cation-exchange resin DOWEX-MAC-3 was transformed into the acid form by the two-percent hydrochloric acid solution, ion-exchange resin was transformed at the alkali treatment of ion-exchange resin in the acid form into $\mathrm{Na}^{+}$form. The weak-acid ionexchange resin is not regenerated into $\mathrm{Ca}^{2+}, \mathrm{Mg}^{2+}$ and $\mathrm{Cu}^{2+}$ forms by the solution of sodium chloride [3].

The copper on cation-exchange resins was sorbed from the solutions in Artesian and main water at concentrations $3.32,5.30$ and $39.24 \mathrm{mg} / \mathrm{dm}^{3}$. Characteristics of Artesian water:

$$
\begin{aligned}
& H=5.6 \mathrm{mg} \text {-equ } / \mathrm{dm}^{3}, A=5.40 \mathrm{mg} \text {-equ } / \mathrm{dm}^{3}, \\
& C_{\mathrm{Ca}^{2+}}=4.7 \mathrm{mg} \text {-equ } / \mathrm{dm}^{3}, \\
& C_{\mathrm{Mg}^{2+}}{ }^{+}=0.9 \mathrm{mg} \text {-equ } / \mathrm{dm}^{3}, \\
& C_{C l}=282 \mathrm{mg} / \mathrm{dm}^{3}, \\
& C_{\mathrm{SO}_{4}^{2-}}=23 \mathrm{mg} / \mathrm{dm}^{3}, \mathrm{pH}=7.25 .
\end{aligned}
$$

Characteristics of main water:

$H=4.80 \mathrm{mg}$-equ $/ \mathrm{dm}^{3}$,

$C_{\mathrm{Ca}^{2+}}=3.6 \mathrm{mg}$-equ $/ \mathrm{dm}^{3}, C_{\mathrm{Mg}^{2+}}=1.2 \mathrm{mg}$-equ $/ \mathrm{dm}^{3}$,

$A=4.80 \mathrm{mg}$-equ $/ \mathrm{dm}^{3}, C_{C l}=37.6 \mathrm{mg}-\mathrm{equ} / \mathrm{dm}^{3}$,

$C_{S_{4}^{2-}}=49.7 \mathrm{mg}$-equ $/ \mathrm{dm}^{3}, \mathrm{pH}=7.10$.

Sorption was performed by filtering solutions through a layer of ion-exchange resin in the column of $2 \mathrm{~cm}^{3}$ diameter (volume of ion-exchange resin is $10 \mathrm{~cm}^{3}$ ) at the rate of $15 \mathrm{~cm}^{3} / \mathrm{min}$. Regeneration solutions were passed at the rate of $1 \mathrm{~cm}^{3} / \mathrm{min}$. In the purified water the content of copper ions, hardness, alkalinity, level of $\mathrm{pH}$ were controlled. Concentrations of copper ions and hardness ions were controlled by the known methods [4].

\section{Results and Discussion}

It is known that the cation-exchange resin selectivity on double-charged cations mainly depends on the radius of the hydrated cation-exchange resin. Therefore, selectivity of most cation-exchange resins on calcium ions is close to their selectivity on heavy metal ions such as copper, zinc, nickel, as the radii of their hydration shells are fairly close to each other.

In this case, the main factor which affects the ion exchange removal of heavy metals from water is the level of their concentration and hardness ion content in the water. At low concentrations of heavy metal ions removing them from the water with high level of hardness will not be effective. The same applies to copper ions. However, at the ion exchange softening of water removal of copper ions from the water is quite possible, although the capacities of the ion-exchange resin on copper will be far from the maximum ones [5].
As seen from the results shown in Fig. 1, at the concentration of copper in the artesian water at the level of $1.234 \mathrm{mg}$-equ/dm $\mathrm{dm}^{3}$, which is by 4.5 times lower compared to the concentration of hardness ions, exchange capacity of weak-acid cation-exchange resin DOWEXMAC-3 on copper reaches 1548 and $1733 \mathrm{mg}$-equ/ $/ \mathrm{dm}^{3}$, which is only by $\sim 2$ times lower than its capacity for hardness ions (3095 and $3620 \mathrm{mg}$-equ/ $\mathrm{dm}^{3}$, respectively). In general, the given ion-exchange resin has a high capacity [6] in the salt form. In this case it sorbs copper at the concentration of $3.32 \mathrm{mg}$-equ/dm $\mathrm{dm}^{3}$ (Fig. 1, curve 2). In the acid form it sorbs cation-exchange resins only in the presence of hydrocarbonate anion-exchange resins (at the high alkalinity of water).

This is due to the fact that the water acidification occurs at the sorption of cations on the cation-exchange resin in the acid form. If the hydrocarbonate of anions is present, they can bind protons to form the carbonic acid, which is subsequently released as $\mathrm{CO}_{2}$. If the hydrocarbonate of anions is absent at the sorption of cations, the acidification of the solution is happening until dissociated carbonyl groups of cation-exchange resin transfer into the associate form, that is inactive at ion exchange, at low $\mathrm{pH}$ values.

$$
\begin{gathered}
2 \mathrm{R}-\mathrm{C}(\mathrm{O}) \mathrm{O}^{-} \mathrm{H}^{+}+\mathrm{Ca}^{2+}+2 \mathrm{HCO}_{3}^{-} \rightarrow \\
\rightarrow\left[\mathrm{RC}(\mathrm{O}) \mathrm{O}^{-}\right]_{2} \mathrm{Ca}^{2+}+\mathrm{H}_{2} \mathrm{CO}_{3} \\
\mathrm{R}-\text { polymer matrix. } \\
\mathrm{H}_{2} \mathrm{CO}_{3} \rightarrow \mathrm{H}_{2} \mathrm{O}+\mathrm{CO}_{2} \\
\stackrel{\mathrm{RC}^{+}(\mathrm{O}) \mathrm{O}^{-} \mathrm{H}^{+} \underset{\mathrm{H}^{+}}{\rightleftarrows} \mathrm{RC}(\mathrm{O}) \mathrm{OH}}{\mathrm{H}^{+}}
\end{gathered}
$$

It provides a fairly deep decarbonization of water (Fig. 1, curve 8) and its acidification (Fig. 2, curve 1) at the filtering through this cation-exchange resin in the acid form, to transit cation-exchange resin in the salt form. Thus, $\mathrm{pH}$ is reduced to $3.8-4.2$, that conduces $\mathrm{CO}_{2}$ excretion from water.

In total, for the water with alkalinity which is close to hardness (Fig. 1), rather high capacity was observed for the ion-exchange resin either on copper ions, or on hardness ions. But because of acidification of the solution and reduction of the dissociation degree of carboxyl groups of the cation-exchange resin its capacity according to the given ions is slightly lower compared with the ionexchange resin in the salt form (Fig. 2, curve 2), which ion exchange takes place according to the reaction (4):

$$
\begin{aligned}
& 2 \mathrm{RC}(\mathrm{O}) \mathrm{O}^{-} \mathrm{Na}^{+}+\mathrm{MX}_{2} \Leftrightarrow \\
& \Leftrightarrow\left(R C(O) O^{-}\right)_{2} M+2 \mathrm{NaX} \\
& \mathrm{M}-\mathrm{Ca}^{2+}, \mathrm{Mg}^{2+}, \mathrm{Cu}^{2+} ; \mathrm{X}-\operatorname{anion}\left(\mathrm{Cl}^{-}, \mathrm{HCO}_{3}^{-}\right)
\end{aligned}
$$




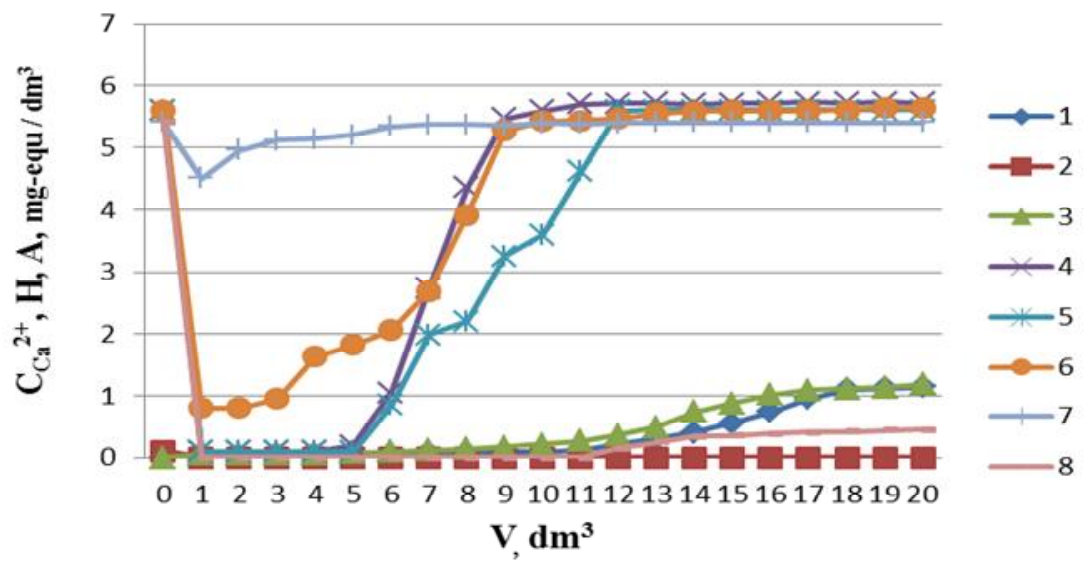

Fig. 1. The dependence of the initial concentration of copper ions $(1 ; 2 ; 3)$, hardness $(4 ; 5 ; 6)$, alkanity $(7 ; 8)$ on the transmitted volume of Artesian water $\left(H=5.6 \mathrm{mg}\right.$-equ $/ \mathrm{dm}^{3}, A=5.4 \mathrm{mg}$-equ $/ \mathrm{dm}^{3}, C_{C a}{ }^{2+}=4.7 \mathrm{mg}$-equ $/ \mathrm{dm}^{3}$;

$C_{M g}{ }^{2+}=0.9 \mathrm{mg}$-equ $\left./ \mathrm{dm}^{3} ; C_{C l}=82 \mathrm{mg} / \mathrm{dm}^{3}\right)$ with a concentration of copper ions $39.24 \mathrm{mg} / \mathrm{dm}^{3}(1 ; 3 ; 4 ; 6 ; 7)$ and $3.32 \mathrm{mg} / \mathrm{dm}^{3}(2 ; 5 ; 8)$ through the cation- exchange resin Dowex-MAC-3 in the $\mathrm{Na}^{+}(1 ; 2 ; 4 ; 5 ; 7)$ and $H^{+}(3 ; 6 ; 8)$ form $\left(V_{i}=10 \mathrm{~cm}^{3}\right)$.

$\left(\mathrm{EDC}_{1}=1733 \mathrm{mg}\right.$-equ $/ \mathrm{dm}^{3} ; \mathrm{EDC}_{2}=207 \mathrm{mg}$-equ $/ \mathrm{dm}^{3} ; \mathrm{EDC}_{3}=1548 \mathrm{mg}$-equ $/ \mathrm{dm}^{3} ;$ $\mathrm{EDC}_{4}=3620 \mathrm{mg}$-equ $/ \mathrm{dm}^{3} ; \mathrm{EDC}_{5}=4458 \mathrm{mg}$-equ $/ \mathrm{dm}^{3} ; \mathrm{EDC}_{6}=3095 \mathrm{mg}$-equ $\left./ \mathrm{dm}^{3}\right)$

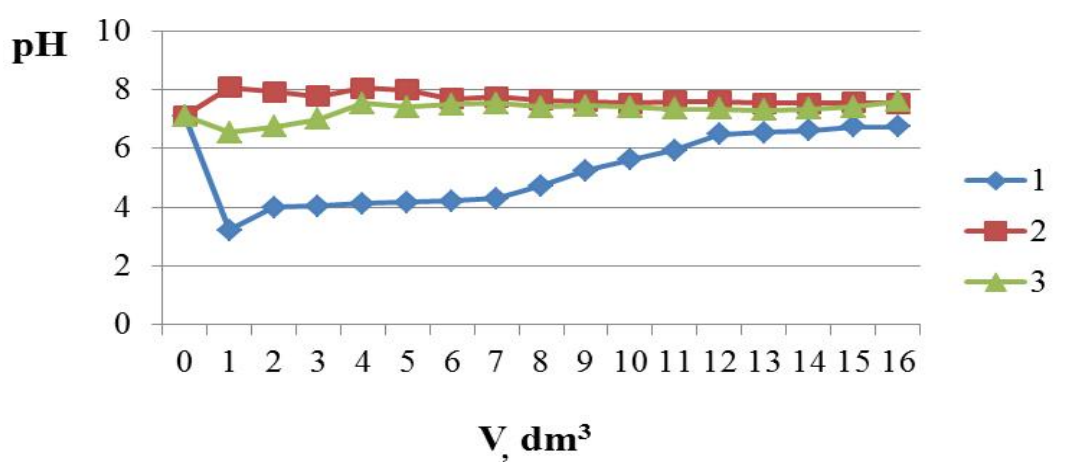

Fig. 2. Change of pH of main water $\left(H=4.8 \mathrm{mg}\right.$-equ $/ \mathrm{dm}^{3},\left[\mathrm{Ca}^{2+}\right]=3.6 \mathrm{mg}$-equ $/ \mathrm{dm}^{3} ;\left[\mathrm{Mg}^{2+}\right]=1.2 \mathrm{mg}$-equ $/ \mathrm{dm}^{3}$; $A=4.8 \mathrm{mg}$-equ $\left./ \mathrm{dm}^{3}\right)$ depending on the volume transmitted through the cation-exchange resin Dowex-MAC-3 in the $H^{+}$form $\left(V_{i}=10 \mathrm{~cm}^{3}\right)(1), \mathrm{KU}-2-8$ in the $\mathrm{Na}^{+}$form $\left(V_{i}=10 \mathrm{~cm}^{3}\right)(2)$, and successively through the cation-exchange resin Dowex-MAC-3 in the $\mathrm{H}^{+}$form $\left(V_{i}=10 \mathrm{~cm}^{3}\right)$ and the cation-exchange resin KU-2-8 in $\mathrm{Na}^{+}$form $\left(V_{i}=10 \mathrm{~cm}^{3}\right)(3)$

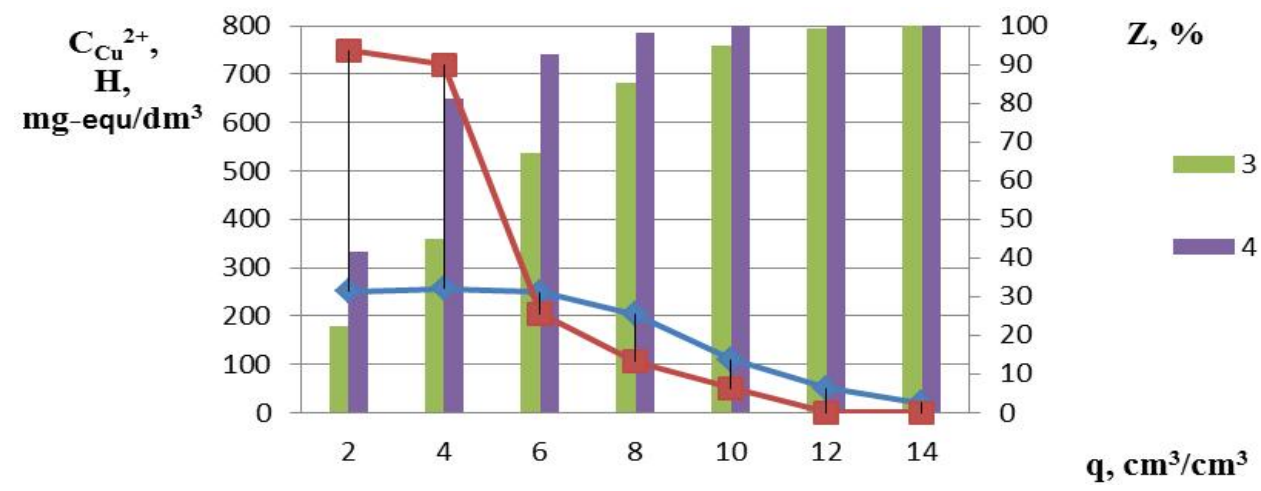

Fig. 3. Dependence of copper ions (1) and hardness ions (2) concentration,

the desorption degree of copper ions (3) and hardness ions (4) on the specific consumption of 1- $n$ solution of hydrochloric acid through the weak-acid cation-exchange resin Dowex-MAC-3 $\left(V_{i}=10 \mathrm{~cm}^{3}\right)$ in $\mathrm{Cu}^{2+}, \mathrm{Ca}^{2+}, \mathrm{Mg}^{2+}$ form 
The advantage of the weak-acid cation-exchange resin is its high regeneration efficiency in acid medium [6, 7] which was confirmed by the results shown in Fig. 3.

As shown in the figure, the principal amount of copper and hardness ions is desorbed at the specific consumption of the regeneration solution of $8 \mathrm{~cm}^{3} / \mathrm{cm}^{3}$ of the ion-exchange resin. Thus, after the first test the total content of cations in mg-equ in the solution was equal to its acidity. So the ion-exchange resin regeneration occurs with a slight excess of acid reagent. This is due to the fact that in the acidic environment carboxyl groups of the ionexchange resin transform into the associate form that facilitates the desorption of cation-exchange resins of metals. However, like most weak-acid cation-exchange resins [3], this cation-exchange resin in $\mathrm{Ca}, \mathrm{Mg}$ and $\mathrm{Cu}$ form is not regenerated by salt solutions $\left(\mathrm{NaCl}, \mathrm{Na}_{2} \mathrm{SO}_{4}\right.$, etc.) regardless of their concentrations. This is also true for other double- and triple-charged cation-exchange resins, sorbed on the weak-acid cation-exchange resin DOWEX-MAC-3.

The main disadvantage of this cation-exchange resin is that when it is used at the water softening the acidification happens in the acid form. On the one hand, it provides its full calcination and high stability on calcareous sediments. On the other hand, the acidified water is corrosive and is not suitable for use in most technological processes. The use of a cation-exchange resin salt $\left(\mathrm{Na}^{+}\right)$form is complicated by the fact that its transfer to the $\mathrm{Na}^{+}$form during regeneration is possible only with sequential processing by the solution of acid and alkali, which is non-technological.

It is known that high efficiency at the cationic softening of water is provided by cation-exchange resin KU2-8 in $\mathrm{Na}^{+}$form. As our study has shown (Fig. 4), this cationexchange resin, along with the softening of water, provides a sufficiently effective removal of copper ions. Although it has a somewhat lower capacity for the copper ions and hardness ions compared to weak-acid cation-exchange resin DOWEX-MAC-3, its advantage is the easiness of regeneration, accessibility and relatively low price.

As shown in Fig. 4, the cation-exchange resin KU2-8 in the $\mathrm{Na}^{+}$form provides the effective softening of water in the presence of copper ions. Exchange dynamic capacity (EDC) of the ion-exchange resin on hardness ions was $2.947 \mathrm{mg}$-equ $/ \mathrm{dm}^{3}$. On copper its capacity was only $179 \mathrm{mg}$-equ $/ \mathrm{dm}^{3}$. However, in all samples copper concentration after cation-exchange resin did not exceed $0.28 \mathrm{mg} / \mathrm{dm}^{3}$ at the initial concentration of $5.3 \mathrm{mg} / \mathrm{dm}^{3}$. It is obvious that in the situation where the ion-exchange resin transformed into the $\mathrm{Ca}^{2+}$ and $\mathrm{Mg}^{2+}$ form, it could still sorb copper ions for some time. It is known that this ion-exchange resin sorbs copper ions in the $\mathrm{Ca}^{2+}$ form [8]. However, at such low concentrations of copper ions up to the presence of dynamic equilibrium on copper ions dozens of $\mathrm{dm}^{3}$ of water are needed to be passed at the ionexchange resin volume equal to $10 \mathrm{~cm}^{3}$. This experiment shows that the cation-exchange resin KU-2-8 sorbs the copper ions from water even at its low concentrations at the hardness equal to $4.8 \mathrm{mg}$-equ/ $\mathrm{dm}^{3}$.

The interesting result is the high efficiency of desorption of copper ions in the process of salt regeneration of the cation-exchange resin (Fig. 5). In case of iron sorption the regeneration was complicated by the oxidation of iron(II) to iron(III) and the hydrolysis of the latter [9]. At pH levels of 7.10-8.09 (Fig. 2, curve 2) copper salts are not hydrolyzed and therefore they are effectively desorbed at the treatment with sodium chloride solution. Even better conditions for sorption and desorption of copper are at the sequential use of the cation-exchange resin DOWEX-MAC-3 in the acid form and $\mathrm{KU}-2-8$ in the $\mathrm{Na}^{+}$form. Then $\mathrm{pH}$ of the solution does not go beyond the limits of 7.10-7.60.

The advantage of the salt regeneration of the cation-exchange resin KU-2-8 (10\% solution of sodium chloride) is the simplicity of treatment and replenishment of the regeneration solution. At its treatment by alkali and soda solutions in the quantities which are equivalent to the content of calcium and magnesium, and also copper in this case, the deposition of $\mathrm{CaCO}_{3}, \mathrm{Mg}(\mathrm{OH})_{2}, \mathrm{Cu}(\mathrm{OH})_{2}$ occurs [10]. The resulting solution of sodium chloride with a low content of calcium and magnesium provides the same efficiency of regeneration, as the freshly prepared $\mathrm{NaCl}$ solution.

Based on the obtained results we can offer rather simple, low-waste technology of water conditioning for the cooling systems charge in power industry (Fig. 6).

According to this scheme the water from the cooling pond after purification in ultrafiltration installation [1], which provides complete removal of suspended and colloidal impurities and macromolecular solutes, enters the cation exchange filters. Two-stage cationization provides a complete removal of hardness ions as well as the deep purification of water from copper ions. At the first stage of cationization filters work up to the breakthrough of hardness ions at concentrations from 1.5 to $2.0 \mathrm{mg}$-equ/ $\mathrm{dm}^{3}$, which allows the better use of capacity of the cation-exchange resin. At the second stage of cationization filters work up to the breakthrough of hardness ions at $0.1 \mathrm{mg}$-equ/ $/ \mathrm{dm}^{3}$. This allows us to efficiently soften the water and almost completely clean it from copper ions. Thus when reaching the breakthrough, filters of the first stage of cationization are turning off one by one for regeneration, and then they turn on to complete the process of purification of water at the second stage of cationization. Filters of the second stage of cationization switch to the water purification from the cooling pond after the breakthrough of the hardness ions, i.e. they switch to the first stage of cationization. This allows us to make the best use of cation-exchange resin capacity at both stages of cationization. Regeneration of the cationexchange resin is made with the $10 \%$ solution of sodium chloride at the supply from the tanks (2) and (4). Waste regeneration solutions from the tank (8) come into the reactor (9), where they get treatment by soda and alkali. 


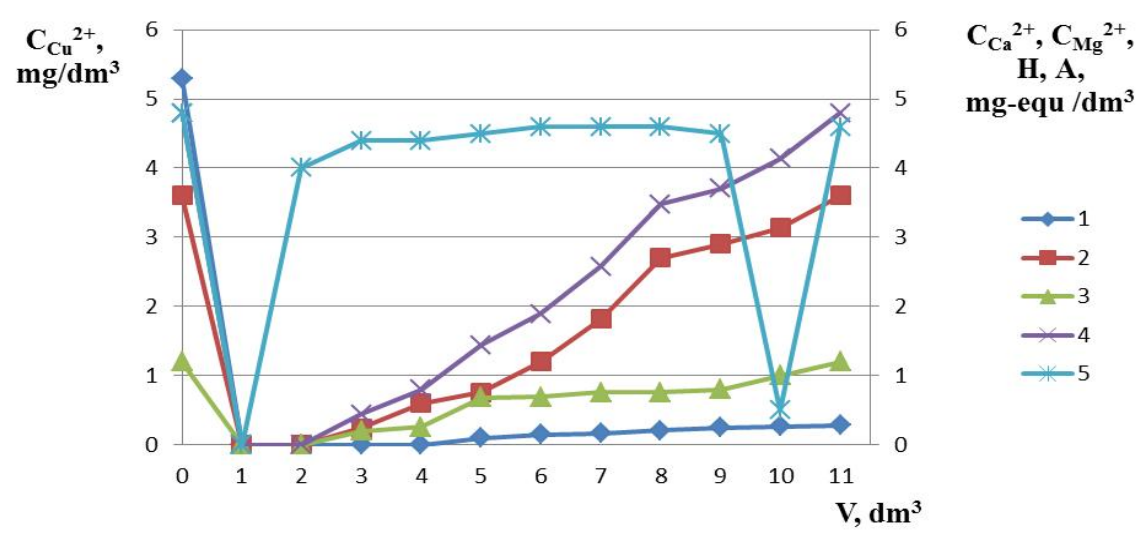

Fig. 4. Dependence of copper (1), calcium (2), magnesium (3) residual concentration, rigidity (4), alkalinity (5) of the copper solution in main water $\left(H=4.8 \mathrm{mg}\right.$-equ $/ \mathrm{dm}^{3}, C_{\mathrm{Ca}}{ }^{2+}=3.6 \mathrm{mg}$-equ $/ \mathrm{dm}^{3}$; $C_{\mathrm{Mg}}{ }^{2+}=1.2 \mathrm{mg}$-equ $/ \mathrm{dm}^{3} ; A=4.8 \mathrm{mg}$-equ $/ \mathrm{dm}^{3}, C_{\mathrm{Cu}}{ }^{2+}=5.3 \mathrm{mg} / \mathrm{dm}^{3}$ ) on the solution volume transmitted through the cation-exchange resin $\mathrm{KU}-2-8$ in the $\mathrm{Na}^{+}$form $\left(V_{i}=10 \mathrm{~cm}^{3}\right)$.

$\left(\mathrm{EDC}_{1}=179 \mathrm{mg}\right.$-equ $/ \mathrm{dm}^{3} ; \mathrm{EDC}_{2}=2262 \mathrm{mg}$-equ $/ \mathrm{dm}^{3} ; \mathrm{EDC}_{3}=685 \mathrm{mg}$-equ $/ \mathrm{dm}^{3} ; \mathrm{EDC}_{4}=2947 \mathrm{mg}$-equ $\left./ \mathrm{dm}^{3}\right)$

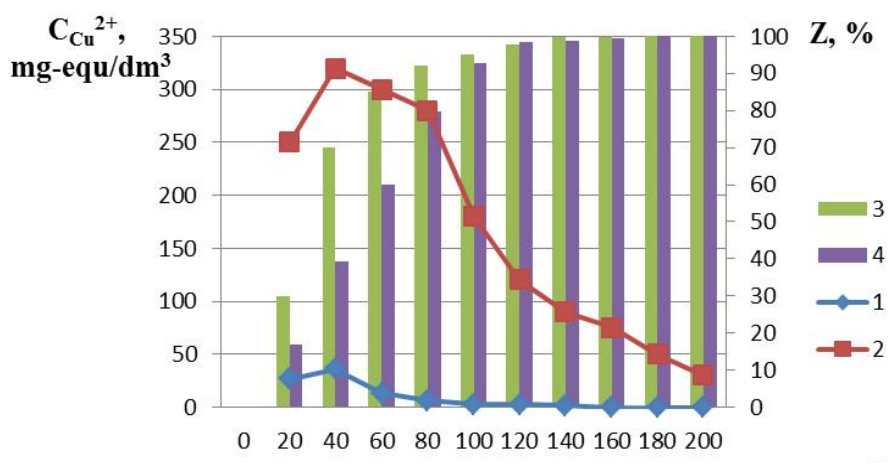

$$
\mathrm{V}, \mathrm{cm}^{3}
$$

Fig. 5. Dependence of copper ions (1) and hardness ions (2) concentration,

the desorption stage of copper (3) and hardness ions (4) on the transmitted volume of the $10 \%$ solution of sodium chloride through the cation-exchange resin KU-2-8 in the $\mathrm{Cu}^{2+}, \mathrm{Mg}^{2+}, \mathrm{Ca}^{2+}$ form $\left(V_{i}=10 \mathrm{~cm}^{3}\right)$

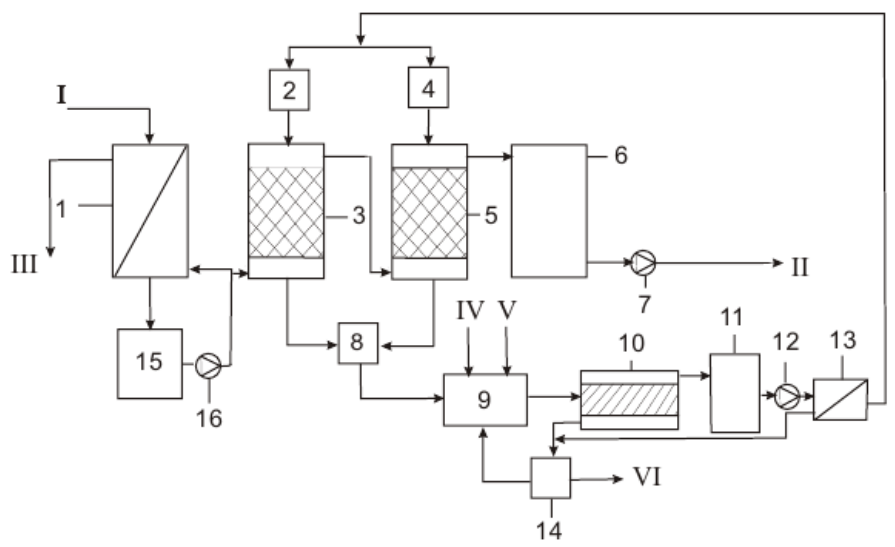

Fig. 6. Principal technological scheme of water treatment plant

for cooling systems of power plants: ultrafiltration filter (1); tanks with $10 \%$ solution of $\mathrm{NaCl}(2,4)$; cation exchange filters (KU-2-8 in the $\mathrm{Na}^{+}$form) $(3,5)$; tank of softened water (6);

pumps $(7,12,16)$; tank of waste regeneration solutions (8); reactor (9); thin layer tank (10);

tank of the clarified solution $\mathrm{NaCl}$ (11); belt filter (13); filter-press (14) and tank of clarified water (15). I - supply of water from the cooling pond; II - supply of water for the cooling system charge; III - rinse water discharge; IV - soda solution supply; V - alkali solution supply; VI - residue for treatment 
Adding soda and alkali in amounts equivalent to the content of calcium and magnesium ions, respectively, the hardness ions mainly convert into insoluble state (Eqs. (5)-(7)):

$$
\begin{aligned}
& \mathrm{CaCl}_{2}+\mathrm{Na}_{2} \mathrm{CO}_{3} \longrightarrow \mathrm{CaCO}_{3} \downarrow+2 \mathrm{NaCl} \\
& \mathrm{MgCl}_{2}+2 \mathrm{NaOH}=\mathrm{Mg}(\mathrm{OH})_{2} \downarrow+2 \mathrm{NaCl} \\
& \mathrm{CuCl}_{2}+2 \mathrm{NaOH}=\mathrm{Cu}(\mathrm{OH})_{2} \downarrow+2 \mathrm{NaCl}
\end{aligned}
$$

The hardness ions residual content does not exceed $2.5 \mathrm{mg}$-equ $/ \mathrm{dm}^{3}$

The residue is released from water in the thin layer tank (10), and then after the filter (13) it is supplied for reuse. The residue, separated in the thin layer tank and the filter, is sent to the manufacturing of materials for building as described in [11]. Note that the reconstituted regeneration solutions of sodium chloride provide high efficiency of regeneration of ion-exchange resin with the increase of its $\mathrm{pH}$ up to 10.5 [3]. But in fact, after the landing of calcium and magnesium ions $\mathrm{pH}$ of the solution is decreased to 8.7-9.5.

From the tank of softened water, water is fed for the cooling systems charging. Cleaning of the ultrafiltration units is performed using the reverse current of the clarified water at the successive disconnection of modules.

Taking into account the amount of copper that comes into the cooling pond of Zaporizhzhya NPP $\sim 18$ tons/year [2], to extract all the copper we need to develop the ion exchange installation with the cationexchange resin capacity equal to $18 \mathrm{~m}^{3}$. In this case, if the capacity of the ion-exchange resin on copper ions is only $100 \mathrm{mg}-\mathrm{equ} / \mathrm{dm}^{3}$, each day $50 \mathrm{~kg}$ of copper will be extracted from water, or 18 tons/year. Thus nearly $10000 \mathrm{~m}^{3}$ of almost completely softened water will be supplied into the cooling systems daily. Under these conditions, the discharge of water on the systems blowing will be significantly reduced at the decrease of concentrations of copper to levels, which are below the acceptable ones at the wastewater discharge.

\section{Conclusions}

1. The processes of water purification from copper ions in the processes of its cation exchange softening are studied. It is shown that the weak-acid cation-exchange resin DOWEX-MAC-3 provides deep decarbonization of water at its satisfactory softening when used in the acid form. Strong- and weak-acid ion-exchange resins provide the water purification from copper in the processes of sodium cation softening.
2. The conditions of the effective regeneration of strong- and weak-acid cation-exchange resins by the solutions of sodium chloride and hydrochloric acid are determined. It is stated that the weak-acid cation-exchange resin is effectively regenerated after the sorption of double-charged cations by the acid solutions. Regeneration by the solutions of sodium chloride is ineffective. $10 \% \mathrm{NaCl}$ solution provides the effective regeneration of the cation-exchange resin KU-2-8 at the high stage of desorption of copper ions.

3 . The low-waste technological scheme of water preparation for the power plants cooling systems has been developed. It ensures deep softening of water with the removal of its copper ions, which can significantly reduce the discharge of water for systems blowing and reduce the discharge of copper to an acceptable level.

\section{References}

[1] Moroz N., Cherkashin N.: Sb. Nauchn. Trudov SIAEiP, 2004, 10, 73.

[2] Moroz N., SednevV., Cherkashin I.: Prom. Teplotehnika, 2005, 27,78 .

[3] Gomelya N., Shablij T., Nosakova Y.: Energotechn. i Resursosberezh., 2004, 4, 55.

[4] Lur'e Y.: Spravochnik po Analiticheskoj Khimii. Khimiya, Moskva 1989.

[5] Makarenko I., NosachovaY., Ivanenko A.: Visnyk NTUU «KPU», 2014, 1, 54.

[6] Makarenko I., Glushko O., Rusyhin V. et al.: East. Eur. J. Adv. Technol., 2012, 57, 16.

[7] Rusyhin V., Glushko O., Makarenko S.: Visnyk Nats. Techn. Univ. "HPU”, 2012, 34, 137.

[8] Shablij T.: East. Eur. J. Adv. Technol., 2010, 45, 10.

[9] Gomelya I., Omelchuk Y., Radovenchik V.: Energotechn. i Resursosberezh., 2008, 3, 62.

[10] Shablij T., Makarenko I., Goltvyanickaya E.: Energotechn. i Resursosberezh., 2010, 1, 53.

[11] Trus I., Flejsher P., Gomelya M. et al.: Visnyk KrNU, 2014, 4, 169.

Received: J une 14, 2016 / Revised: J uly 18, 2016 /

Accepted: J anuary 19, 2017

\section{СТВОРЕННЯ МАЛОВІДХОДНОЇ ТЕХНОЛОГІЇ ОЧИЩЕННЯ ВОДИ ВІД ЙОНІВ МІДІ}

Анотація. Приведено результати досліджень зі стабілізачійного оброблення води для піджсилення водозворотних систем охолодження іонообмінним методом. Вивчено прочеси пом'якшення води на сильно- та слабокислотних катіонітах у присутності йонів міді. Визначено залежність ефективності очищення води від міді та ї̈ пом'якшення в залежності від форми йоніту та витрат води.

Ключові слова: катіоніт, важкі метали, йонний обмін, регенерачія йонітів, водочиркуляиійні системи. 